\title{
Article
}

\section{Improved Production of Streptomyces sp. FA1 Xylanase in a Dual-Plasmid Pichia pastoris System}

\author{
Wei Xia ${ }^{1,2,3}\left(\mathbb{D}\right.$, Mengkai Hu ${ }^{1,2,3}$, Yang Pan ${ }^{1,2,3}$, Dan $\mathrm{Wu}^{2, *}$ and Jing $\mathrm{Wu}{ }^{1,2,3, *}$ \\ 1 State Key Laboratory of Food Science and Technology, Jiangnan University, Wuxi 214122, China; \\ weixia@jiangnan.edu.cn (W.X.); mkaihu@163.com (M.H.); ypan2021@163.com (Y.P.) \\ 2 Key Laboratory of Industrial Biotechnology, School of Biotechnology, Ministry of Education, \\ Jiangnan University, Wuxi 214122, China \\ 3 International Joint Laboratory on Food Safety, Jiangnan University, Wuxi 214122, China \\ * Correspondence: wudan@jiangnan.edu.cn (D.W.); jingwu@jiangnan.edu.cn (J.W.)
}

check for updates

Citation: Xia, W.; Hu, M.; Pan, Y.; Wu, D.; Wu, J. Improved Production of Streptomyces sp. FA1 Xylanase in a Dual-Plasmid Pichia pastoris System. Curr. Issues Mol. Biol. 2021, 43, 2289-2304. https://doi.org/10.3390/ cimb43030161

Academic Editor: Vijai Bhadauria

Received: 29 November 2021 Accepted: 16 December 2021 Published: 18 December 2021

Publisher's Note: MDPI stays neutral with regard to jurisdictional claims in published maps and institutional affiliations.

Copyright: (c) 2021 by the authors. Licensee MDPI, Basel, Switzerland. This article is an open access article distributed under the terms and conditions of the Creative Commons Attribution (CC BY) license (https:// creativecommons.org/licenses/by/ $4.0 /)$.

\begin{abstract}
Methanol is considered as a potential hazard in the methanol-induced yeast expression of food-related enzymes. To increase the production efficiency of recombinant proteins in Pichia pastoris without methanol induction, a novel dual-plasmid system was constructed, for the first time, by a combining the strategies of genomic integration and episomal expression. To obtain a high copy number of the target gene, the autonomously replicating sequence derived from Kluyveromyces lactis (PARS) was used to construct episomal vectors carrying the constitutive promoters $\mathrm{P}_{G A P}$ and $\mathrm{P}_{G C W 14}$. In addition, an integrative vector carrying the $\mathrm{P}_{G C W 14}$ promoter was constructed by replacing the $\mathrm{P}_{G A P}$ promoter sequence with a partial $\mathrm{P}_{G C W 14}$ promoter. Next, using xylanase XynA from Streptomyces sp. FA1 as the model enzyme, recombination strains were transformed with different combinations of integrating and episomal vectors that were constructed to investigate the changes in the protein yield. Results in shake flasks indicated that the highest enzyme yield was achieved when integrated $P_{G A P}$ and episomal $P_{G C W 14}$ were simultaneously transformed into the host strain. Meanwhile, the copy number of $x y n A$ increased from $1.14 \pm 0.46$ to $3.06 \pm 0.35$. The yield of XynA was successfully increased to $3925 \mathrm{U} \cdot \mathrm{mL}^{-1}$ after $102 \mathrm{~h}$ of fermentation in a $3.6 \mathrm{~L}$ fermenter, which was 16.7-fold and 2.86-fold of the yields that were previously reported for the constitutive expression and methanol-induced expression of the identical protein, respectively. Furthermore, the high-cell-density fermentation period was shortened from $132 \mathrm{~h}$ to $102 \mathrm{~h}$ compared to that of methanol-induced system. Since the risk of methanol toxicity is removed, this novel expression system would be suitable for the production of proteins related to the food and pharmaceutical industries.
\end{abstract}

Keywords: Pichia pastoris; non-methanol induction; dual plasmid; promoter $\mathrm{P}_{G C W 14}$; xylanase

\section{Introduction}

The methylotrophic yeast Pichia pastoris, one of the most effective and convenient industrial expression systems [1-5], has been widely used for the production of various heterologous proteins because of its unique advantages, including simple nutritional requirements, growth to a very high cell density, simple purification methods, diverse post-transcriptional modifications, and tight regulation of the induction process [6-8]. To date, more than 1000 heterologous proteins have been successfully expressed using this system [9-14].

Two types of promoter elements are commonly used in the P. pastoris expression system: inducible promoters, represented by the methanol-induced $\mathrm{P}_{A O X}$ promoter [15], and constitutive promoters, represented by the constitutive glyceraldehyde 3-phosphate dehydrogenase $\mathrm{P}_{G A P}$ promoter [16] and the newly discovered constitutive GCW14 cell wall protein $\mathrm{P}_{G C W 14}$ promoter [17]. $\mathrm{P}_{A O X}$ is the strongest promoter currently known and can strictly 
control the expression of heterologous proteins under induction with methanol [18-20]. Although many proteins have been successfully expressed using the $\mathrm{P}_{A O X}$ promoter, the use of methanol in large-scale production processes has many drawbacks, including difficulty in measuring the concentration of methanol because of its volatility, the potential fire hazard, and unsuitability for production of food proteins because of its toxicity [6,21]. These serious disadvantages of the $\mathrm{P}_{A O X}$ promoter have prompted research on other promoters. The constitutive $P$. pastoris expression system carrying the $\mathrm{P}_{G A P}$ promoter is the most commonly applied methanol-free system, which does not require methanol for heterologous expression, and could be cultivated in a continuous high-cell-density fermentation mode [16,22]. However, its expression efficiency is much weaker than that of $\mathrm{P}_{A O X}$ [23-27]. Another recently identified constitutive promoter, $\mathrm{P}_{G C W 14}$, has an equally strong transcription initiation intensity and significantly shorter fermentation time compared to that of $P_{A O X}[17,28]$. Therefore, expression systems carrying $P_{G C W 14}$ are expected to replace those carrying $\mathrm{P}_{A O X}$ for the large-scale production of heterologous proteins, particularly proteins used in the food and healthcare industries, which need higher safety requirements [29-31].

According to the differences in the locations of gene expression cassettes between different types of vector plasmids, heterologous genes generally exist in P. pastoris in two forms, integrated and episomal [32]. Integrated expression refers to restructuring heterologous genes into the yeast genome through specific homologous sequences, while heterologous genes in episomal plasmids exist in the cytoplasm of yeast cells and are dissociative from the genome without integration. Integrating heterologous genes for expression into the chromosome of $P$. pastoris was once considered to be more stable than using episomal vectors, but the integration sites have been shown to be adjacent and heterologous genes may be lost by homologous recombination under certain conditions [33]. Either the $\mathrm{pPIC} 9 \mathrm{~K}, \mathrm{pPICZ} \alpha$, and $\mathrm{pGAPZ} \alpha$ plasmids are usually integrated into the yeast genome alone, or simultaneously in some cases, to control and enhance the expression level in recombinant strains [34-38]. However, integrative expression can also adversely affect the yeast's own physiological metabolism and integration of high-copy heterologous genes into the genome was found to reduce the growth rate and cell activity of recombinant yeasts. Consequently, the integration of heterologous genes into the yeast genome may also result in genetic instability of the host cells, leading to floating and a decrease of the expression level [39]. In contrast, episomal vectors are replicated independently in host cells, leading to benefits such as a significantly increased copy number of inserted genes and little effect on the host genome $[10,40]$. The autonomously replicating sequence (ARS) on episomal plasmids is the key factor for the stable maintenance of episomal plasmids in host cells [9,41-44]. A recently identified autonomously replicating sequence derived from Kluyveromyces lactis (PARS) has a stronger replication ability than ARS sequences A76 and C937 from P. pastoris itself $[45,46]$. Although the use of episomal vectors to express heterologous proteins in yeast expression systems has certain advantages, there have been few studies on heterologous protein expression in P. pastoris using episomal vectors [26]. A stronger constitutive glycosylphosphatidylinositol (GPI) anchoring protein (GCW14) promoter $\mathrm{P}_{G C W 14}$ was found, through which the constitutive expression of Candida antarctica lipase B (CALB) [17] and Thermomyces dupontii thermo-alkaline lipase [47] were higher than $\mathrm{P}_{G A P}$ and $\mathrm{P}_{\text {TEF1 }}$ promoters. Liang and colleagues used the constitutive promoter $\mathrm{P}_{G C W 14}$ to express green fluorescent protein (EGFP) based on glycerol and methanol as carbon sources. The green fluorescent protein (EGFP) expressed through the $\mathrm{P}_{G C W 14}$ promoter is about 10 times more intense than the $P_{G A P}$ promoter [28]. It can be seen that the $P_{G C W 14}$ promoter has a significant advantage in the expression of heterologous proteins in Pichia pastoris.

Xylanase is widely used in diverse industries, including papermaking, pasta production, xylooligosaccharide preparation, fruit and vegetable production, and in feed additives [48-50]. In our previous study, a xylanase used in food, XynA from Streptomyces sp. FA1 (NCBI accession number: JX560161), was expressed in P. pastoris using methanol induction with an enzyme activity of $1374 \mathrm{U} \cdot \mathrm{mL}^{-1}$ [51]. In the present study, a strat- 
egy combining episomal expression and genomic integrative expression was designed to further improve the expression level of xylanase XynA, and also eliminate the risk of methanol contamination. A new integrative vector carrying the $\mathrm{P}_{G C W 14}$ promoter was constructed by partially replacing the $\mathrm{P}_{G A P}$ promoter sequence with the $\mathrm{P}_{G C W 14}$ promoter. The remaining fragment of the $P_{G A P}$ promoter was reserved as the integrating sequence. The autonomously replicating sequence from $K$. lactis (PARS) was inserted into a pGAPZ $\alpha$ plasmid backbone for the construction of episomal plasmids carrying the constitutive $\mathrm{P}_{G A P}$ or $\mathrm{P}_{\text {GCW14 }}$ promoter. Next, different combinations of integrating and episomal plasmids were transformed into the host cell to explore the yield of XynA. This work was aimed to develop a novel dual-plasmid $P$. pastoris expression system to achieve high expression levels without methanol induction, which is of great value for the production of proteins or enzymes with high safety requirements.

\section{Materials and Methods}

\subsection{Strains and Chemicals}

The host strains E. coli JM109 and P. pastoris KM71 were purchased from Invitrogen (Carlsbad, CA, USA). The expression vectors pMD18-T-simple, pGAPZ $\alpha$ A, and pPPIC9K were purchased from Novagen (Shanghai, China). The vector pMD18-T- $x y n A$ was stored in our laboratory. The restriction enzymes Not I, EcoR I, Avr II, and T4 DNA ligase were purchased from Takara (Dalian, China). Primer synthesis and DNA sequencing were conducted by Shanghai Sangon Biological Engineering Technology \& Services Co., Ltd. (Shanghai, China). Beechwood xylan was purchased from Sigma-Aldrich (X4252-25G, St. Louis, MO, USA). The growth mediums YPD, MD, BMGY, BMMY, BSM, G418 (Invitrogen, CA, USA), and zeocin (Sangon Biotech, Shanghai, China) were prepared according to the Multi-Copy Pichia Expression Kit (Invitrogen, Carlsbad, CA, USA). Other chemicals were of analytical grade and were purchased from Sinopharm Chemical Reagent Co., Ltd. (SCRC, Shanghai, China). An In-Fusion HD cloning kit was purchased from Takara (639648, Japan).

\subsection{Construction of the Episomal Vector $p G C W 14 Z \alpha A-P A R S$}

The newly constructed episomal vector, pGCW14Z $\alpha$ A-PARS, was designed to be capable of self-replication and amplification outside of the host genome and contained the strong constitutive promoter, $\mathrm{P}_{G C W 14}$. First, the $\mathrm{P}_{G A P}$ promoter in the commercial vector pGAPZ $\alpha A$ was substituted with the $P_{G C W 14}$ promoter (see left part of Figure 1a). The $\mathrm{P}_{\text {GCW14 }}$ promoter (NCBI accession number: XM_002490678) was amplified from the $P$. pastoris genome using the primer set $\mathrm{gcw}-\mathrm{F} 1 / \mathrm{gcw}-\mathrm{R} 1$, and the vector backbone without the $\mathrm{P}_{G A P}$ promoter was amplified from the $\mathrm{pGAPZ} \alpha \mathrm{A}$ plasmid using the primer set gap-F1/gap-R1. The two fragments were purified and ligated using Takara's In-Fusion HD cloning kit to obtain the promoter substituted vector pGCW14Z $\alpha$ A. Next, the Pichia autonomously replicating sequence (PARS) was artificially synthesized and inserted at the position downstream of the pUC origin in the pGCW14Z $\alpha$ A plasmid by the same method described above using primer sets pars-F1/pars-R1 and gcw-F2/gcw-R2 to obtain the episomal plasmid pGCW14Z $\alpha$ A-PARS. All primers used for plasmid construction are shown in Table S1 (See Supplementary Materials). 

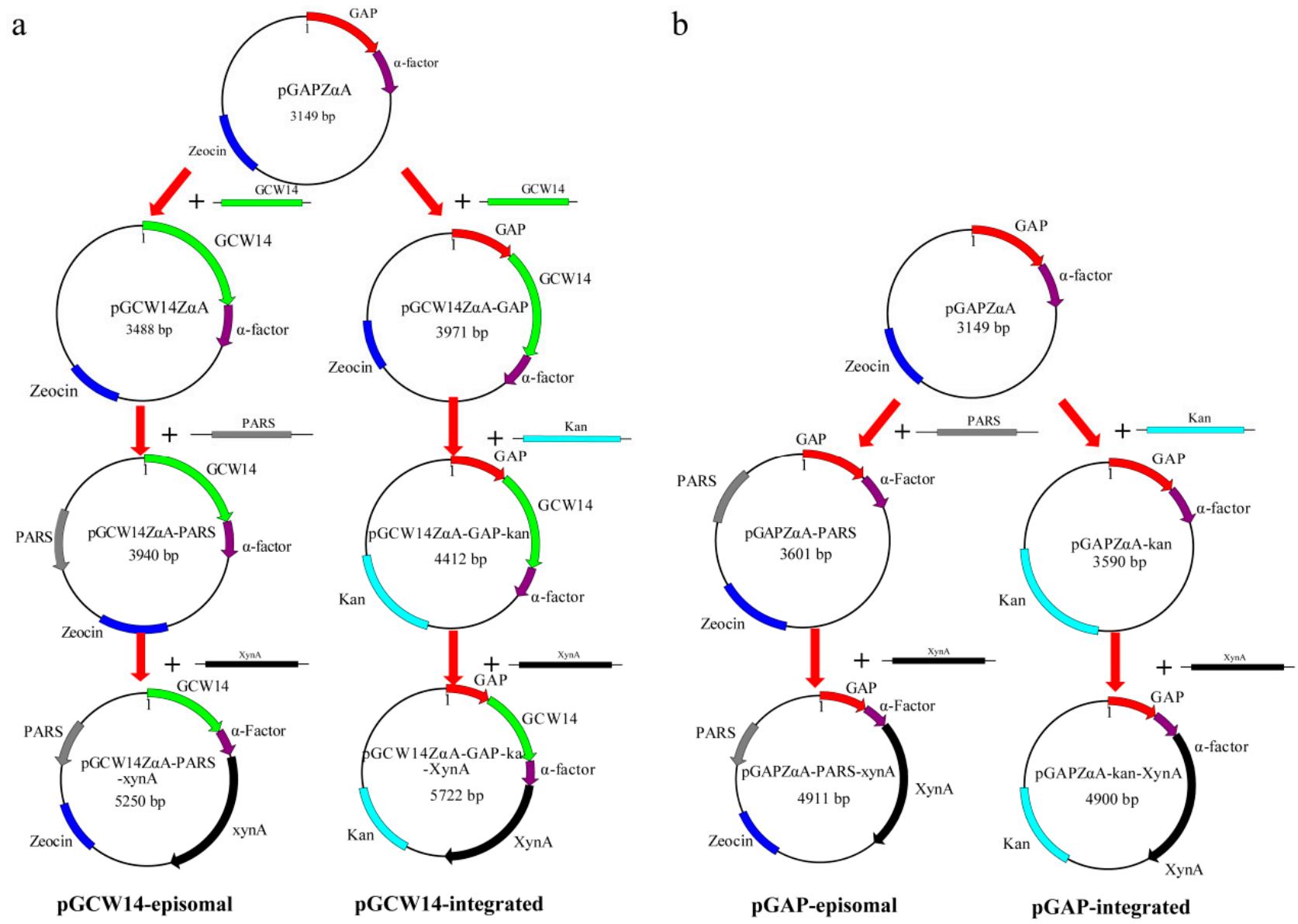

Figure 1. The construction process of episomal or integrative vectors. (a) Construction of vectors carrying the $P_{G C W 14}$ promoter; (b) Construction of vectors carrying the $\mathrm{P}_{G A P}$ promoter.

\subsection{Construction of the Integrated Vector $p G C W 14 Z \alpha A-G A P-K a n$}

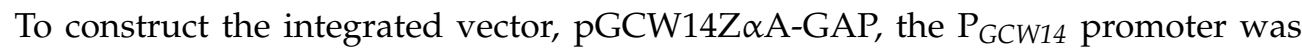
inserted downstream of the $P_{G A P}$ promoter in the commercial vector pGAPZ $\alpha A$ (shown in Figure 1a). The sequence of the $P_{G A P}$ promoter was employed as the integrated site. For detail, the $\mathrm{P}_{G C W 14}$ promoter fragment was amplified from the $\mathrm{pGCW14Z} \alpha \mathrm{A}$ vector using the primer set $\mathrm{gcw}-\mathrm{F} 3 / \mathrm{gap}-\mathrm{R} 1$, and the vector backbone was amplified from the pGAPZ $\alpha$ A commercial vector using the primer set gcw-F1/gap-R2. The two fragments were purified and ligated using Takara's In-Fusion HD cloning kit to obtain the integrated vector pGCW14Z $\alpha$ A-GAP. Next, the Zeocin resistance gene was substituted for the G418 resistance gene for convenient transformant screening. The vector backbone without the Zeocin resistance gene was amplified from the pGCW14Z $\alpha$ A-GAP vector using the primer set gcw-F4/gcw-R3, and the G418 resistance gene fragment was amplified from the pPIC9K commercial vector using the primer set kan-F/kan-R. The two fragments were also purified and ligated to obtain the integrated vector pGCW14Z $\alpha$ A-GAP-Kan.

\subsection{Construction of the Episomal Vector $p G A P Z \alpha A-P A R S$ and the Integrated Vector $p G A P Z \alpha A-K a n$}

The episomal vector containing the PGAP promoter, pGAPZ $\alpha$ A-PARS, was obtained by inserting the PARS sequence at the position downstream of the pUC origin in the pGAPZ $\alpha$ A commercial vector (left part of Figure 1b). Additionally, the integrated vector containing the PGAP promoter, pGAPZ $\alpha \mathrm{A}-\mathrm{Kan}$, was obtained from the pGAPZ $\alpha \mathrm{A}$ commercial vector by replacing the Zeocin resistance with G418 resistance using primer sets gcw-F4/gcw-R3 and kan-F/kan-R (right part of Figure 1b). 


\subsection{Construction of Recombinant Vectors for Xylanase Expression}

The coding sequence of xylanase XynA was amplified from pMD18-T-xynA and inserted into the four vectors described above using the restriction sites EcoR I and Not I for xylanase expression. The constructed recombinant vectors, pGCW14Z $\alpha$ A-PARSXynA, pGCW14Z $\alpha$ A-GAP-Kan-XynA, pGAPZ $\alpha$ A-PARS-XynA, and pGAPZ $\alpha$ A-Kan-XynA were abbreviated as pGCW14-episomal, pGCW14-integrated, pGAP-episomal, and pGAPintegrated, respectively.

\subsection{Construction of Recombinant Strains}

Four single-promoter recombinant strains and four dual-plasmid recombinant strains were constructed in this study as shown in Figure 2. The two integrated strains containing a single promoter, KM71/pGCW14-integrated and KM71/pGAP-integrated, were constructed by integrating the expression cassettes of pGCW14-integrated and pGAPintegrated, respectively, into the host genome. First, both of the integrative vectors were linearized by the restriction enzyme Avr II and transformed into $80 \mu \mathrm{L}$ of P. pastoris KM71 competent cells by electroporation using a Gene Pulser electroporator (Eppendorf, Hamburg, Germany). Next, $1 \mathrm{~mL}$ of pre-cooled $1 \mathrm{M}$ sorbitol solution was added and blown gently. The cells were transferred to a $1.5 \mathrm{~mL}$ EP tube and incubated at $30^{\circ} \mathrm{C}$ and $200 \mathrm{rpm}$ for $2 \mathrm{~h}$. Transformants were screened on MD plates after incubation for 2-3 days at $30^{\circ} \mathrm{C}$, and further screened using YPD plates containing various concentrations of G418 $\left(1.0-2.0 \mathrm{mg} \cdot \mathrm{mL}^{-1}\right)$.

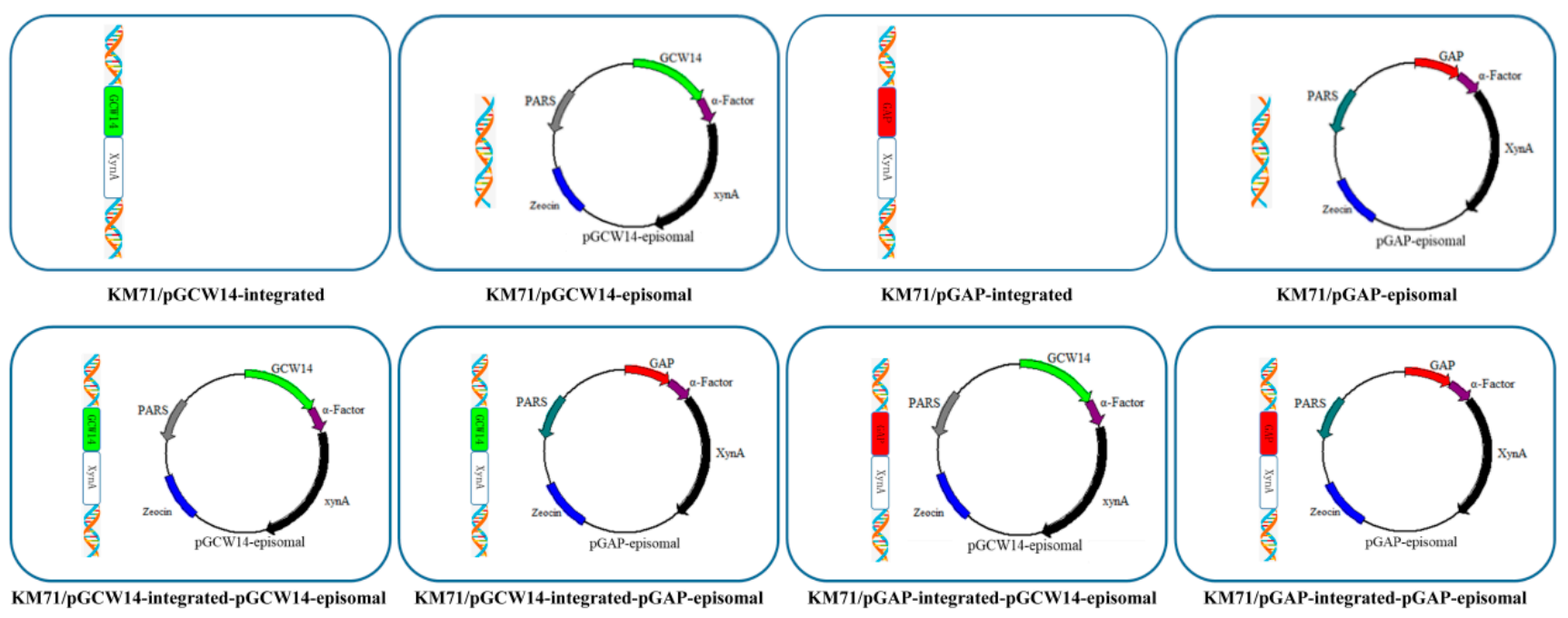

Figure 2. The construction process of the eight recombinant P. pastoris KM71 strains with different expression patterns.

The two episomal strains containing a single promoter, KM71/pGCW14-episomal and KM71/pGAP-episomal, were obtained by directly transforming the vectors pGCW14episomal and pGAP-episomal, respectively, into P. pastoris KM71 competent cells without linearization. Positive transformants were identified using YPDS plates containing $100 \mu \mathrm{g} \cdot \mathrm{mL}^{-1}$ of Zeocin. The four dual-plasmid strains containing a combination of episomal and integrative vectors, KM71/pGCW14-integrated-pGAP-episomal, KM71/pGCW14integrated-pGCW14-episomal, KM71/pGAP14-integrated-pGCW14-episomal, and KM71/ pGAP-integrated-pGAP-episomal, were constructed by transforming the episomal vectors into the competent cells of integrated strains and screening positive transformants on YPDS plates containing $100 \mu \mathrm{g} \cdot \mathrm{mL}^{-1}$ of Zeocin.

\subsection{Culturing Recombinant Strains in Shake Flasks}

Recombinant strains were grown in $10 \mathrm{~mL}$ of YPD medium at $30{ }^{\circ} \mathrm{C}$ in a shaker (200 rpm) for $24 \mathrm{~h}$. Next, $2.5 \mathrm{~mL}$ of culture solution was withdrawn and inoculated into 
$50 \mathrm{~mL}$ of YPD medium containing an additional $4 \%$ glycerol. The supernatant was collected after $84 \mathrm{~h}$ of culturing to detect the yield of xylanase.

\subsection{Determination of Genetic Stability of Episomal Vectors}

Single colonies of constructed strains containing the $X y n A$ gene were picked into $2 \mathrm{~mL}$ of YPD liquid medium and cultured overnight at $30^{\circ} \mathrm{C}$ in a $10 \mathrm{~mL}$ shake flask (200 rpm). Next, $1 \%$ of the culture was inoculated into fresh YPD liquid medium, and cultured in a $50 \mathrm{~mL}$ shake flask at $30{ }^{\circ} \mathrm{C}$ and $200 \mathrm{rpm}$ for 2 days. YPD medium was transferred once every two days and sampled, and then the sample was appropriately diluted, coated on a non-selective YPD plate, and cultured at $30^{\circ} \mathrm{C}$. After colony growth, single colonies were randomly picked and seeded on non-selective YPD plates and selective YPD plates (containing $100 \mu \mathrm{g} \cdot \mathrm{mL}^{-1}$ zeocin). The stability of the foreign gene in recombinant strain was determined by comparing the growth numbers of both.

\subsection{High Density Fermentation in a 3.6 L Bioreactor}

The recombinant strain was cultured in a $3.6 \mathrm{~L}$ fermenter (Labfors 5, Infors-HT Co., Ltd., Bottmingen, Switzerland) using a constant-rate-fed carbon source mode. The basic medium consisted of $26.7 \mathrm{~mL} \cdot \mathrm{L}^{-1}$ of $85 \%$ phosphoric acid, $0.93 \mathrm{~g} \cdot \mathrm{L}^{-1} \mathrm{CaSO}_{4}, 18.2 \mathrm{~g} \cdot \mathrm{L}^{-1}$ $\mathrm{K}_{2} \mathrm{SO}_{4}, 14.9 \mathrm{~g} \cdot \mathrm{L}^{-1} \mathrm{MgSO}_{4} \cdot 7 \mathrm{H}_{2} \mathrm{O}, 4.13 \mathrm{~g} \cdot \mathrm{L}^{-1} \mathrm{KOH}, 40.0 \mathrm{~g} \cdot \mathrm{L}^{-1}$ glycerol, $4.35 \mathrm{~mL} \cdot \mathrm{L}^{-1} \mathrm{PTM} 1$, and histidine $2.0 \mathrm{~g} \cdot \mathrm{L}^{-1} .80 \%$ glycerol (histidine $5 \mathrm{~g} \cdot \mathrm{L}^{-1}$ ) was added to maintain the carbon source content during the fermentation. The $\mathrm{pH}$ of the culture was adjusted to 5.0 using $100 \%$ ammonium hydroxide. The dissolved oxygen was controlled at $30 \%$ by adjusting the stirring speed and the aeration amount. The dissolved oxygen in the early fermentation is adjusted by the rotation speed. When the maximum rotation speed reaches $800 \mathrm{rpm}$, pure oxygen is passed into the fermentation to maintain the dissolved oxygen. The supernatant was taken every $12 \mathrm{~h}$ to determine enzyme activity, DCW $\left(\mathrm{g} \cdot \mathrm{L}^{-1}\right)$, and protein concentration. Glycerol was fed at different speeds $(4 \%, 6 \%, 10 \%, 12 \%)$ at the carbon-feed stage, and the $10 \%$ flow rate was $17.3 \mathrm{~g}$ of feed per hour.

\subsection{Enzyme Activity Assay and Protein Concentration Assay}

The substrate was prepared by dissolving $0.5 \mathrm{~g}$ of xylan from beechwood in $100 \mathrm{~mL}$ of $50 \mathrm{mM}$ phosphate buffer ( $\mathrm{pH}$ 5.5) and mixing well. The reaction mixture consisted of $1 \mathrm{~mL}$ of the above substrate and $1 \mathrm{~mL}$ of appropriately diluted enzyme. After incubation at $50{ }^{\circ} \mathrm{C}$ for $10 \mathrm{~min}, 3 \mathrm{~mL}$ of 3,5-dinitrosali-cylic acid (DNS) was added to stop the reaction. The reaction solution was boiled for $10 \mathrm{~min}$, rapidly cooled, distilled to a volume of $20 \mathrm{~mL}$ with distilled water, and the absorbance was measured at $540 \mathrm{~nm}$ (the inactivated enzyme solution that was used as a catalyst was also used as a blank control), and the released xylose equivalent was calculated according to a previously built standard curve. One unit $(\mathrm{U})$ of xylanase activity is defined as the amount of enzyme that releases $1 \mu \mathrm{mol}$ of reducing sugar per minute from beechwood xylan at $50{ }^{\circ} \mathrm{C}$ and $\mathrm{pH} 5.5$ [51]. The protein concentration was determined by the Bradford method with bovine serum albumin (BSA) solutions with gradient concentrations as the standards.

\subsection{Genomic DNA Extraction and Gene Copy Number Analysis by qPCR}

The recombinants were inoculated into $50 \mathrm{~mL} \mathrm{YPD}$ and cultured at $30^{\circ} \mathrm{C}$ for $24 \mathrm{~h}$. The yeast culture was then centrifuged at 10,000 rpm for $15 \mathrm{~min}$ to collect the cell pellet. Liquid nitrogen was added to the cell pellet, and then the cell wall was broken by grinding. Next, $150 \mathrm{mg}$ of the above sample was resuspend in $700 \mu \mathrm{L}$ of $\mathrm{pH} 8.0$ buffer containing $100 \mathrm{mmol} \cdot \mathrm{L}^{-1}$ Tris-HCI, $10 \mathrm{mmol} \cdot \mathrm{L}^{-1}$ EDTA, and $1 \%$ SDS, and incubated at $65{ }^{\circ} \mathrm{C}$ for $1 \mathrm{~h}$. The tube was then vortexed briefly and centrifuged at 10,000 rpm for $15 \mathrm{~min}$. The supernatant was extracted twice with $700 \mu \mathrm{L}$ of chloroform/isoamyl alcohol (24:1). Next, $0.1 \mathrm{~mL}$ of $3 \mathrm{M}$ sodium acetate ( $\mathrm{pH}$ 5.2) solution, $6 \mu \mathrm{L}$ of RNaseA $\left(10 \mathrm{~g} \cdot \mathrm{L}^{-1}\right)$, and $1 \mathrm{~mL}$ of pre-cooled absolute ethanol were added into the aqueous phase. The liquid was incubated at $-20{ }^{\circ} \mathrm{C}$ for $30 \mathrm{~min}$ to precipitate the DNA completely and then centrifuged at $5000 \mathrm{rpm}$ 
for $10 \mathrm{~min}$. before the pellet was washed once with $70 \%$ ethanol, air-dried, and redissolved in $50 \mu \mathrm{L} \mathrm{TE}$ buffer under $65^{\circ} \mathrm{C}$ for $10 \mathrm{~min}$.

GAPDH (accession number XM_002491300) was chosen as the reference gene to detect the copy number of the target gene $(x y n A)$ in the recombinant strains using the qPCR method. Two sets of qPCR primers were designed (shown in Table S2). The TB Green ${ }^{\mathrm{TM}}$ Premix Ex Taq ${ }^{\mathrm{TM}}$ II kit (Takara Bio-Inc, Otsu, Japan) and Applied Biosystems StepOnePlus Real-Time PCR System (Thermo Fisher Scientific, Waltham, MA, USA) were used. During the qPCR reaction, the reaction mixture was pre-incubated at $95^{\circ} \mathrm{C}$ for $30 \mathrm{~s}$ for DNA denaturation and then subjected to 40 cycles, which were $5 \mathrm{~min}$ at $95^{\circ} \mathrm{C}$ and $30 \mathrm{~s}$ at $60^{\circ} \mathrm{C}$. The $\Delta \mathrm{Ct}$ method was used to calculate the copy number of the target gene in Pichia pastoris.

\section{Results}

\subsection{XynA Expressions in Single-Promoter Strains in Shake Flasks}

The expression levels of XynA in strains containing different episomal and integrative vectors carrying $\mathrm{P}_{G A P}$ and $\mathrm{P}_{G C W 14}$ promoters were compared at a shake flask scale. As shown in Table 1, the expression levels in strains containing episomal vectors were found to be higher than those containing integrative vectors. In particular, the expression level in the strain containing the episomal vector pGCW14-episomal increased 2.82-fold compared to that of the strain containing the integrative vector pGCW14-integrated, demonstrating the advantage of episomal vectors for the expression of heterologous proteins in P. pastoris. Further, enzyme activity in the strain containing pGCW14-episomal vectors also increased 2.92-fold compared with that in the strain containing pGAPZ $\alpha$ A-episomal vectors, indicating that the initiation efficiency of $\mathrm{P}_{G C W 14}$ was much higher than that of $\mathrm{P}_{G A P}$ in the episomal pattern. However, the enzyme activity in the strain containing the pGAPZ $\alpha \mathrm{A}$ episomal vector had no significant increase compared with the pGAPZ $\alpha \mathrm{A}$-integrated vector, probably due to the weak initiation ability of the $\mathrm{P}_{G A P}$ promoter that could not significantly increase xylanase expression levels, even when used as an episomal vector.

Table 1. Xylanase activities of recombinant strains with a single promoter in shake flasks.

\begin{tabular}{ccccc}
\hline Strains & $\begin{array}{c}\text { pGCW14- } \\
\text { Episomal }\end{array}$ & $\begin{array}{c}\text { pGCW14- } \\
\text { Integrated }\end{array}$ & $\begin{array}{c}\text { pGAP- } \\
\text { Episomal }\end{array}$ & $\begin{array}{c}\text { pGAP- } \\
\text { Integrated }\end{array}$ \\
\hline $\begin{array}{c}\text { Activity } \\
\left(\mathrm{U} \cdot \mathrm{mL}^{-1}\right)\end{array}$ & $94.3 \pm 7.6^{\mathrm{a}}$ & $33.4 \pm 2.1^{\mathrm{b}}$ & $32.3 \pm 2.5^{\mathrm{b}}$ & $27.8 \pm 1.9^{\mathrm{c}}$ \\
\hline
\end{tabular}

Note: Activity data was presented as mean \pm standard deviation of triplicate determinations. The different letters indicate a statistically significant difference at $p<0.05$ level for different strains.

\subsection{Stability of the $p$ GCW14-Episomal Vector in the Host Cell}

It is important to improve the genetic stability of episomal vectors in recombinant strains to avoid adding antibiotics and thus decreasing of expression levels during the whole period (134 h) of fermentation. A previous study reported that the retention rate of PARS vectors after culture for ten generations with and without antibiotics were $97.3 \%$ and $39.04 \%$, respectively [46]. However, the method for measurement of vector stability was not clearly presented. In the present study, the pGCW14-episomal vector was constructed using the autonomously replicating sequence PARS and its genetic stability in P. pastoris was investigated by repeated experiments. Results indicated that the recombinant $P$. pastoris strain containing pGCW14-episomal had a high genetic retention rate of $84.71 \%$ by losing only $15.29 \%$ of episomal vectors after the cultured passage for 90 generations (Table 2). P. pastoris was generally considered to reproduce 29 generations every $48 \mathrm{~h}$. Therefore, the time for the reproduction of 90 generations was sufficient to support the growth of host cells for more than $144 \mathrm{~h}$, which fully met the growth requirements of industrial, large-scale fermentation of $P$. pastoris. In other words, there was no risk of losing the coding gene of recombinant proteins when using the pGCW14-episomal vector during the whole period of fermentation. 
Table 2. The genetic stability of the pGCW14-episomal plasmid in the host cell.

\begin{tabular}{cccc}
\hline \multirow{2}{*}{ Generations } & \multicolumn{2}{c}{ Number of Colonies } & \multirow{2}{*}{ Gene Losing Rate } \\
\cline { 2 - 3 } & Non-Selective & Resistance Selective & \\
\hline 30 & 143 & 140 & $2.1 \%$ \\
60 & 144 & 133 & $7.64 \%$ \\
90 & 170 & 144 & $15.29 \%$ \\
\hline
\end{tabular}

\subsection{Enhanced XynA Expressions in Dual-Plasmid Strains in Shake Flasks}

Novel P. pastoris expression systems capable of simultaneous genomic integrative expression and episomal vector expression were constructed by different combinations of two constitutive promoters, $\mathrm{P}_{\mathrm{GAP}}$ and $\mathrm{P}_{\mathrm{GCW}} \mathrm{w}$, to increase the expression level of $\mathrm{XynA}$. Enzyme activities in the recombinant strains KM71/pGAP-integrated-pGCW14-episomal and KM71/pGCW14-integrated-pGCW14-episomal reached $132.7 \pm 9.7 \mathrm{U} \cdot \mathrm{mL}^{-1}$ and 112.9 $\pm 7.2 \mathrm{U} \cdot \mathrm{mL}^{-1}$, respectively (data shown in Table 3). These expression levels were more than 2.2-fold higher than those in strains containing the pGAP-episomal vector, indicating that the $\mathrm{P}_{G C W 14}$ promoter has a much higher initiation efficiency than the $\mathrm{P}_{G A P}$ promoter in episomal mode, which is in accordance with the results in single-promoter strains. When $\mathrm{P}_{G A P}$ and $\mathrm{P}_{\mathrm{GCW14}}$ were integrated separately into the genome for the initiation of expression, expression levels were similar, whereas expression level in the KM71/pGAP-integratedpGCW14-episomal strain was higher than that in the KM71/pGCW14-integrated-pGCW14episomal strain. It indicated that competition might occur when the same promoter was used for simultaneous cytoplasmic episomal expression and genomic integrated expression, which is not conducive to the expression of heterologous proteins. However, when the $\mathrm{P}_{G A P^{-}}$ episomal vector was included in the dual-plasmid system, no significant improvement in enzyme activity was observed in the pGCW14-integrated-containing recombinant strain compared with the KM71/pGAP-integrated strain, showing approximately equal yields of about $50 \mathrm{U} \cdot \mathrm{mL}^{-1}$ and indicating that the expression pattern of genomic integration might severely limit the initiation efficiency of $\mathrm{P}_{\mathrm{GCW} 14}$. The low efficiency of genomic integrative expression could probably be attributed to the complex structure of chromosomes, in which DNA molecules are compressed several thousand times from their primary structure to their quaternary structure [52], resulting in much lower transcription initiation efficiency of heterologous genes in the host genome than in simple episomal vectors.

Table 3. Xylanase activities of recombinant strains with dual plasmids in shake flasks.

\begin{tabular}{ccccc}
\hline Strains & $\begin{array}{c}\text { pGCW14-Integrated } \\
\text {-pGAP-Episomal }\end{array}$ & $\begin{array}{c}\text { pGAP-Integrated } \\
\text {-pGCW14-Episomal }\end{array}$ & $\begin{array}{c}\text { pGAP-Integrated } \\
\text {-pGAP-Episomal }\end{array}$ & $\begin{array}{c}\text { pGCW14-Integrated } \\
\text {-pGCW14-Episomal }\end{array}$ \\
\hline Activity $\left(\mathrm{U} \cdot \mathrm{mL}^{-1}\right)$ & $49.1 \pm 3.5^{\mathrm{a}}$ & $132.7 \pm 9.7^{\mathrm{b}}$ & $49.8 \pm 3.7^{\mathrm{a}}$ & $112.9 \pm 7.2^{\mathrm{c}}$ \\
\hline
\end{tabular}

Note: Data was presented as mean \pm standard deviation of triplicate determinations. The different letters indicate a statistically significant difference at $p<0.05$ level for different strains.

\subsection{Gene Copy Number Analysis}

The expression levels of xylanase in different strains were significantly different. In order to better understand the reasons affecting the gene expression level, the representative strains were selected for qPCR analysis in this study. The detailed amplification data are shown in Table S3, and the melt curves and amplification plots are shown in Figure S1. As a result, there were significant differences in the copy number of different recombinant strains. The copy number of the integrated strain KM71/pGAP-integrated was 1.14, the copy number of the episomal strains KM71/pGAP-episomal and KM71/pGCW14-episomal were 2.05 and 2.03, respectively, and the copy number of the new dual-plasmid strain KM71/pGCW14-episomal-pGAP-integrated was 3.06 (Figure 3). The results indicated that the up-regulation of the XynA gene was one of the reasons for the increase in the expression level of the target gene. 


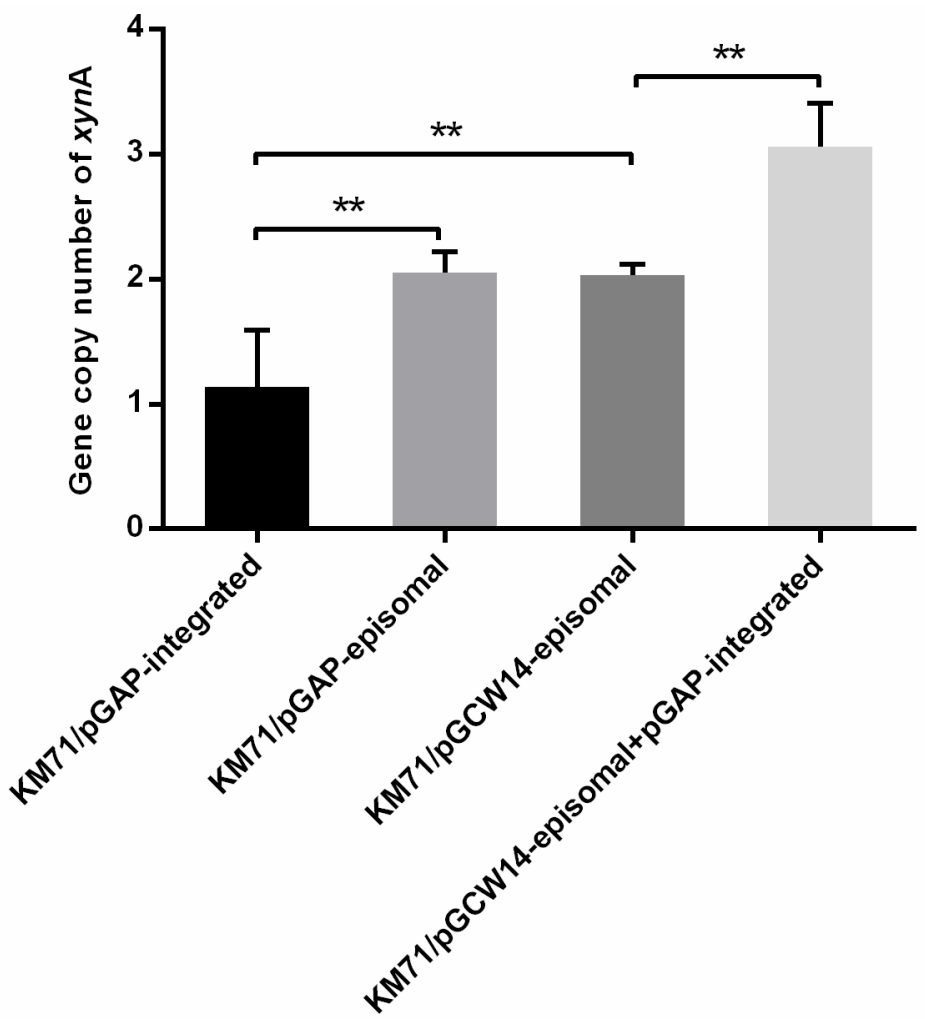

Figure 3. The gene copy number of $x y n \mathrm{~A}$ in four recombinant strains of P. pastoris KM71 with different vector combinations. Symbol ${ }^{* *}$ represents that the difference is statistically significant. The significance of difference was analyzed by one-way ANOVA method.

\subsection{Optimization of Feed-Flow Rate of the Carbon Source during Fermentation in the 3.6 L} Fermenter

Glycerol was chosen as the carbon source for high-cell-density fermentation in a $3.6 \mathrm{~L}$ fermenter of the recombinant strain KM71/pGAP-integrated-pGCW14-episomal, which achieved the highest expression level in the shake flask fermentation. Different constant feed-flow rates of glycerol $(4 \%, 6 \%, 10 \%$, and $12 \%)$ were investigated to maximize the expression level of XynA and shorten the fermentation time cycle as much as possible. The main fermentation parameters and comparison of results are shown in Table 4 . Results showed that both xylanase activity and protein concentration in the fermentation supernatant reached a maximum when the feed-flow rate of glycerol was 10\% (Figure 4a). After $20 \mathrm{~h}$ of fermentation at the $12 \%$ feed-flow rate, the dissolved oxygen was close to zero. When pure oxygen was supplied to the fermenter and fermentation was carried out for another $20 \mathrm{~h}$, the dissolved oxygen again decreased to zero. After that, the growth and expression efficiency of the yeast was significantly reduced, indicating that when the glycerol supply reached a certain level, fast growth of the yeast depleted dissolved oxygen. This affected further growth of the host cells, thereby inhibiting the expression of the heterologous protein. Enzyme activity under the 10\% feed-flow rate reached a maximum at $102 \mathrm{~h}$ of cultivation, which was $23.5 \%$ shorter than the culture time of $126 \mathrm{~h}$ under $4 \%$ and $6 \%$ feed-flow rates. At the $10 \%$ glycerol feeding rate, the enzyme activity, protein concentration, and biomass yield reached $3925 \pm 323.8 \mathrm{U} \cdot \mathrm{mL}^{-1}, 13.6 \pm 1.1 \mathrm{~g} \cdot \mathrm{L}^{-1}$, and 8.59 $\pm 0.69 \mathrm{IU} \cdot \mathrm{OD}_{600}{ }^{-1}$, respectively, which were $33.5 \%, 34.6 \%$, and $7.6 \%$ higher than the values under the $6 \%$ feed-flow rate, respectively (Figure 4). Among them, glycerol was fed at different speeds $(4 \%, 6 \%, 10 \%$, and $12 \%)$ at the carbon feed stage, and the $10 \%$ flow rate was $17.3 \mathrm{~g}$ of feed per hour.

The specific activities under four feed-flow rates were similar, indicating that the structure of the recombinant XynA had no improper change and was not affected by the expression rate. In contrast, the rapid expression of the recombinant protein during 
methanol induction affected the protein structure and caused a significant decrease in specific activities [53]. Further, the highest specific activity of the fermentation broth reached $330.8 \mathrm{U} \cdot \mathrm{mg}^{-1}$, which was increased significantly compared to the data of $87 \mathrm{U} \cdot \mathrm{mg}^{-1}$ in our previous study [54]. It was possibly due to the larger unit-time productive capacity of XynA reducing the interference of other secreted host proteins. As shown in the SDS-PAGE analysis of the fermentation supernatant of the KM71/pGAP-integrated-pGCW14-episomal strain in the 3.6 L fermenter (Figure 5), a protein of the predicted size ( $43.0 \mathrm{kDa})$ for XynA was the main band, which also showed obvious xylanase activity. It could be confirmed that XynA was the primary expression product during the whole period.

Table 4. Comparison of XynA yields of the recombinant strain pGAP-integrated-pGCW14-episomal under different feed-flow rates of glycerol in a 3.6 L fermenter.

\begin{tabular}{ccccc}
\hline \multirow{2}{*}{ Yield } & \multicolumn{4}{c}{ Feed Flow Rates of Glycerol } \\
\cline { 2 - 5 } & $\mathbf{4 \%}$ & $\mathbf{6 \%}$ & $\mathbf{1 0} \%$ & $\mathbf{1 2} \%$ \\
\hline DCW $\left(\mathrm{g} \cdot \mathrm{L}^{-1}\right)$ & 162.68 & 191.1 & 239.12 & 241.08 \\
Protein Conc. $\left(\mathrm{g} \cdot \mathrm{L}^{-1}\right)$ & $5.2 \pm 0.37^{\mathrm{a}}$ & $10.1 \pm 0.95^{\mathrm{b}}$ & $13.6 \pm 1.1^{\mathrm{c}}$ & $10.65 \pm 0.87^{\mathrm{b}}$ \\
Enzyme activity $\left(\mathrm{U} \cdot \mathrm{mL}^{-1}\right)$ & $1720.3 \pm 153.5^{\mathrm{a}}$ & $2940.4 \pm 210.1^{\mathrm{b}}$ & $3925 \pm 323.8^{\mathrm{c}}$ & $3214 \pm 276.9^{\mathrm{b}}$ \\
Specific activity $\left(\mathrm{U} \cdot \mathrm{mg}^{-1}\right)$ & $330.8 \pm 25.2^{\mathrm{a}}$ & $291.1 \pm 22.3^{\mathrm{b}}$ & $303.3 \pm 28.1^{\mathrm{ab}}$ & $301.7 \pm 27.7^{\mathrm{ab}}$ \\
\hline
\end{tabular}

Note: Data was presented as mean \pm standard deviation of triplicate determinations. The different letters indicate a statistically significant difference at $p<0.05$ level for different data in the same row.

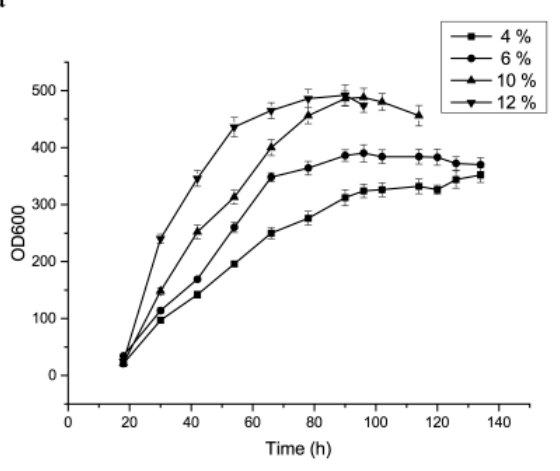

b

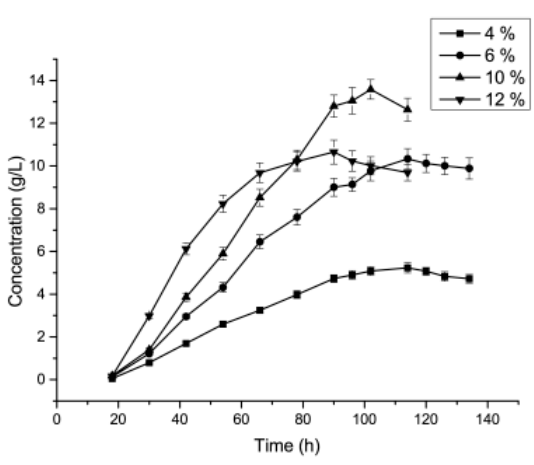

c

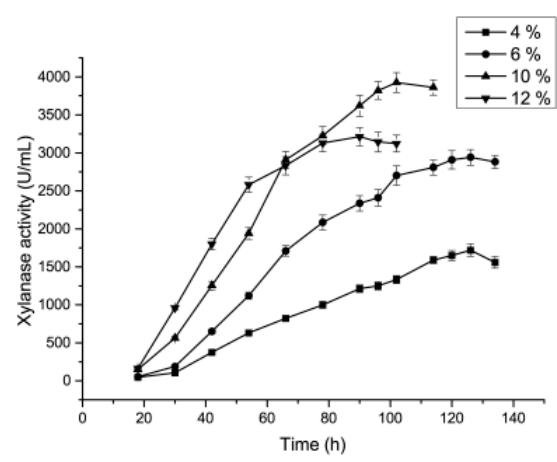

Figure 4. Time course profile of XynA production in the KM71/pGAP-integrated-pGCW14-episomal strain under different carbon-source-feed rates during high-density fermentation in a $3.6 \mathrm{~L}$ fermenter. (a) Enzyme activity of $\mathrm{XynA}$; (b) protein concentration; (c) amount of biomass determined by $\mathrm{OD}_{600} \mathrm{DCW}\left(\mathrm{g} \cdot \mathrm{L}^{-1}\right)$. The different carbon-source-feed rates were respectively marked as $4 \%(\mathbf{( )}), 6 \%(\bullet), 10 \%(\mathbf{\Lambda})$, and $12 \%(\mathbf{\nabla})$.

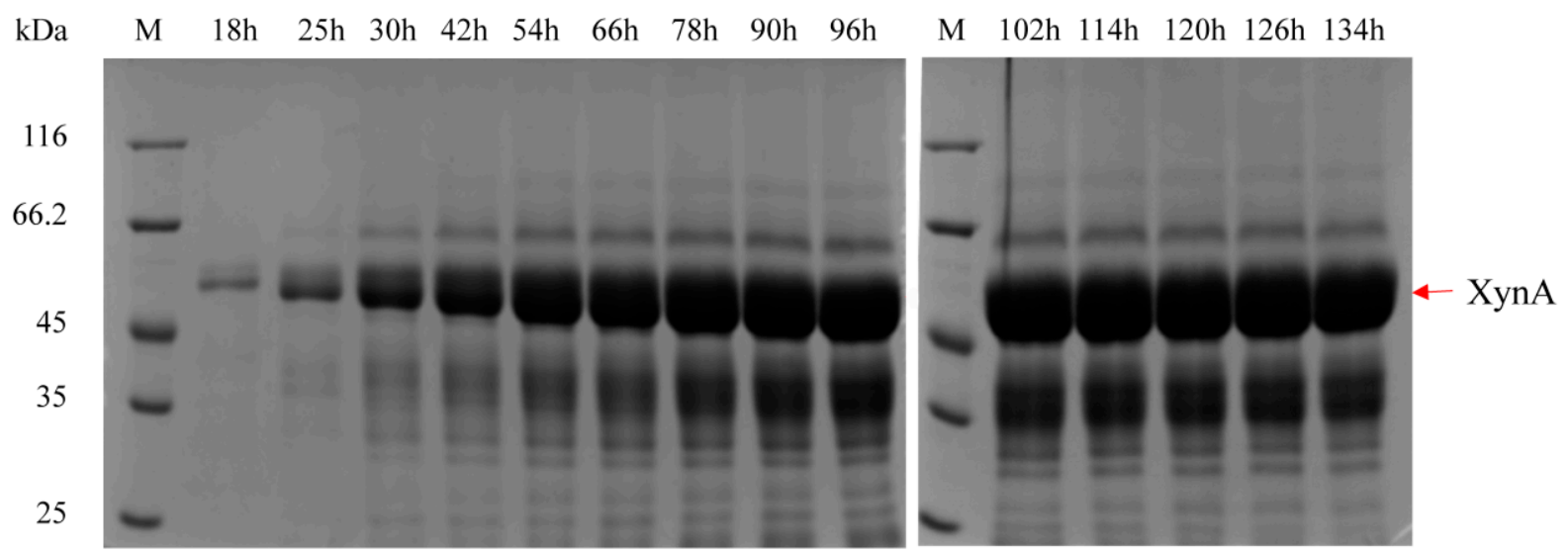

Figure 5. SDS-PAGE analysis of the fermentation supernatant of the recombinant strain KM71/pGAP-integrated-pGCW14episomal at a $10 \%$ glycerol-feeding rate in a $3.6 \mathrm{~L}$ fermenter. 


\subsection{Fermentation of Highly Efficient Recombinant Strains in 3.6 L Fermenter}

The optimized fermentation conditions described above were used to compare the high-cell-density fermentation in a $3.6 \mathrm{~L}$ fermenter of the four recombinant strains, which exhibited high expression efficiency in the shake flask, being the KM71/pGAP-integratedpGCW14-episomal, KM71/pGCW14-integrated-pGCW14-episomal, KM71/pGCW14integrated-pGAP-episomal, and KM71/pGCW14-episomal strains. The highest enzyme activities and the highest protein yields in the four strains were all achieved at approximately $100 \mathrm{~h}$, which verified that the $10 \%$ feed-flow rate of glycerol could indeed shorten the time cycle of high-cell-density fermentation (Figure 6). Furthermore, according to the data shown in Table 5, the total enzyme activities, specific enzyme activities, and amount of protein produced per unit of biomass in the three strains containing the pGCW14-episomal vectors were significantly higher than those in the KM71/pGAP-integrated-pGCW14episomal strain, indicating that the initiation efficiency of $\mathrm{P}_{G C W 14}$ in episomal vectors was still significantly higher than that of $\mathrm{P}_{G A P}$ in the high-density, large-scale fermentation.

a

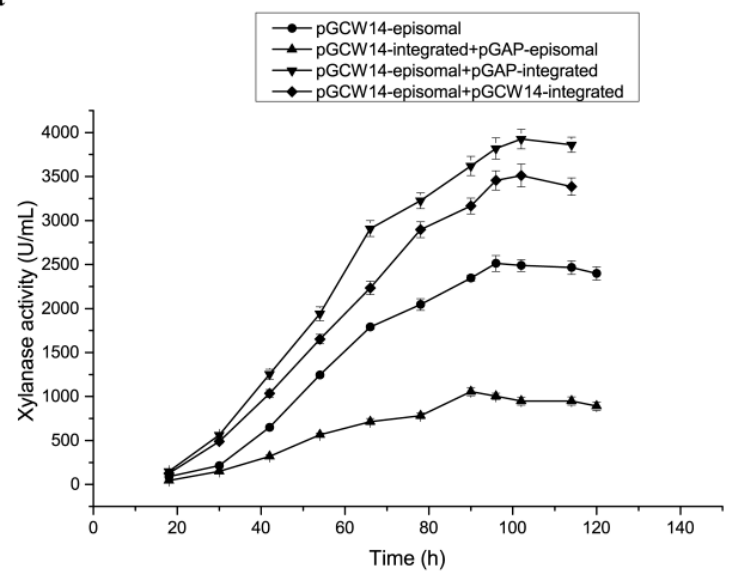

$\mathrm{c}$

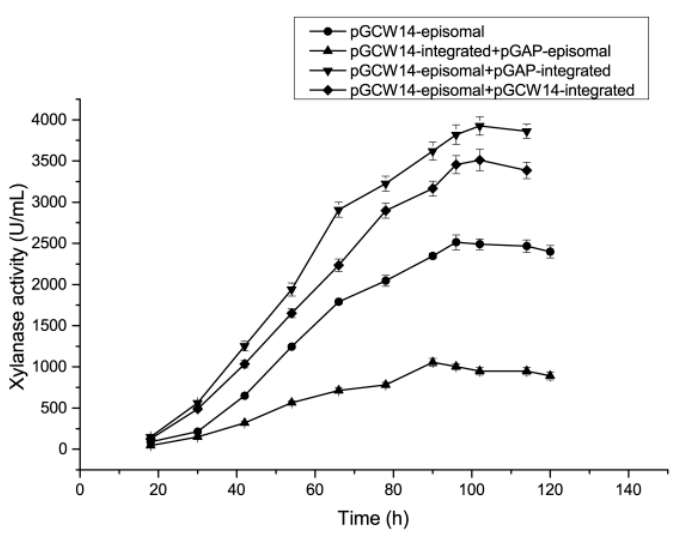

b

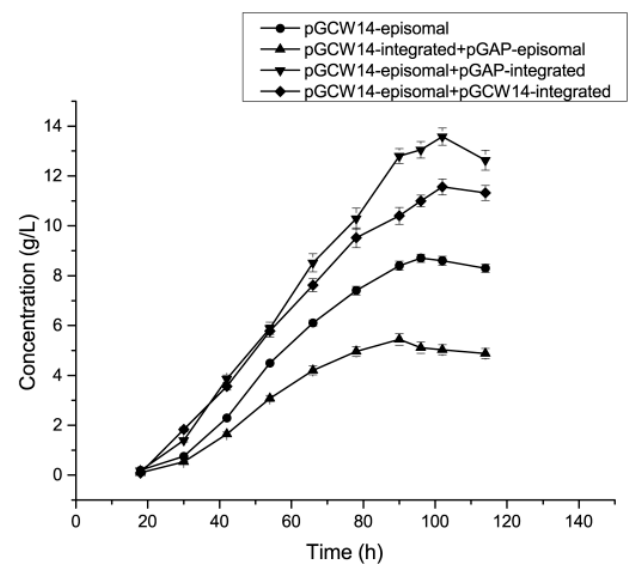

d

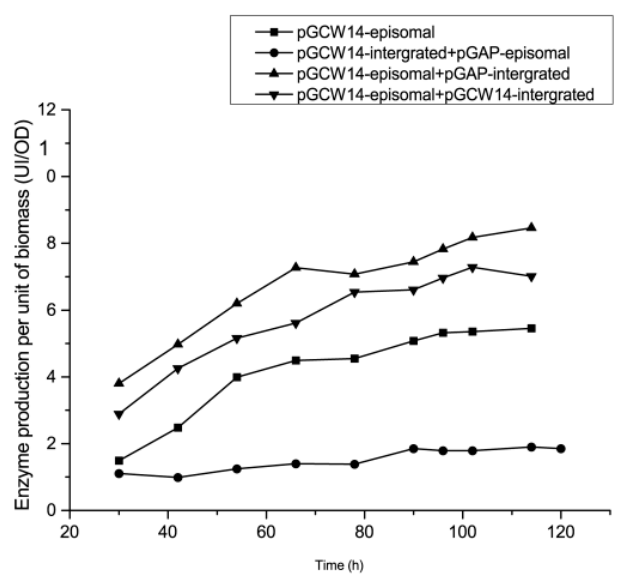

Figure 6. Time-course profile of recombinant xylanase production in constructed P. pastoris strains during high-density fermentation in 3.6 L fermenter. (a) Enzymes activity of XynA; (b) protein concentration; (c) amount of biomass determined by $\mathrm{OD}_{600} \mathrm{DCW}\left(\mathrm{g} \cdot \mathrm{L}^{-1}\right) ;(\mathbf{d})$ yield per unit of biomass. The carbon-source-feed rate was $10 \%$. The strains were respectively marked as $(\bullet)$ KM71/pGCW14-episomal, ( $\mathbf{\nabla})$ KM71/pGAP-integrated-pGCW14-episomal, ( $)$ KM71/pGCW14-integratedpGCW14-episomal, and (ム) KM71/pGCW14-integrated-pGAP-episomal. 
Table 5. Comparison of XynA yields for different recombinant strains in a 3.6 L fermenter.

\begin{tabular}{|c|c|c|c|c|}
\hline Yield $^{a}$ & $\begin{array}{c}\text { DCW } \\
\left(\mathrm{g} \cdot \mathrm{L}^{-1}\right)\end{array}$ & $\begin{array}{l}\text { Protein Conc. } \\
\quad\left(g \cdot L^{-1}\right)\end{array}$ & $\begin{array}{l}\text { Enzyme Activity } \\
\quad\left(\mathrm{U} \cdot \mathrm{mL}^{-1}\right)\end{array}$ & $\begin{array}{l}\text { Specific Activity } \\
\left(\mathrm{U} \cdot \mathrm{mg}^{-1}\right)\end{array}$ \\
\hline KM71/pGAP-integrated $\mathrm{b}$ & 218.3 & 2.7 & 235 & 87 \\
\hline KM71/pGCW14-episomal & 232.24 & $8.7 \pm 0.52^{a}$ & $2512 \pm 193.7^{\mathrm{a}}$ & $298.1 \pm 23.5^{\mathrm{a}}$ \\
\hline KM71/pGCW14-episomal-pGAP-integrated & 239.12 & $13.6 \pm 1.1^{b}$ & $3925 \pm 323.8^{b}$ & $303.3 \pm 28.1^{\mathrm{a}}$ \\
\hline KM71/pGCW14-integrated-pGAP-episomal & 276.36 & $5.4 \pm 0.37^{\mathrm{c}}$ & $1056 \pm 89.2^{\mathrm{c}}$ & $195.6 \pm 15.6^{b}$ \\
\hline KM71/pGAP-integrated-pGAP-episomal & 251.86 & 5.08 & 968.3 & 190.6 \\
\hline KM71/pGCW14-integrated & 237.65 & 4.86 & 847.6 & 174.4 \\
\hline KM71/pGCW14-episomal-pGCW14-integrated & 243.04 & $11.56 \pm 0.92^{b}$ & $3512 \pm 290.3^{b}$ & $303.8 \pm 22.9^{a}$ \\
\hline
\end{tabular}

Note: Data was presented as mean \pm standard deviation of triplicate determinations. The different letters indicate a statistically significant difference at $p<0.05$ level for different strains in the same column. ${ }^{\mathrm{b}}$ Data comes from a previous work of our lab (Pan et al., 2018).

Enzyme activity in the KM71/pGCW14-integrated-pGCW14-episomal strain (3512 \pm $\left.290.3 \mathrm{U} \cdot \mathrm{mL}^{-1}\right)$ was higher than that in the KM71/pGCW14-episomal strain $(2512 \pm 193.7$ $\mathrm{U} \cdot \mathrm{mL}^{-1}$ ), but a little lower than that in the KM71/pGAP-integrated-pGCW14-episomal strain. It indicated that the pGCW14-episomal vectors and the pGCW14-integrated vectors have an additive effect, but the additive effect of promoters with different properties, $\mathrm{P}_{G C W 14}$ and $\mathrm{P}_{G A P}$, was the strongest. Enzyme activity in the KM71/pGAP-integratedpGCW14-episomal strain reached $3925 \pm 323.8 \mathrm{U} \cdot \mathrm{mL}^{-1}$, which is equal to 16.7 -fold of the reported enzyme activity of $235 \mathrm{U} \cdot \mathrm{mL}^{-1}$ in a previously constructed recombinant $P$. pastoris strain containing a pGAP-integrated vector [54]. The specific activity was also increased by 2.3-fold. In addition, when compared with the enzyme activity of $1374 \mathrm{U} \cdot \mathrm{mL}^{-1}$ and specific activity of $218.1 \mathrm{U} \cdot \mathrm{mg}^{-1}$ obtained at $132 \mathrm{~h}$ using methanol to induce the expression of the identical $x y n A$ gene [51], activities achieved in the present work increased by 1.86 -fold and $32.1 \%$, respectively.

\section{Discussion}

The methanol-induced P. pastoris expression system has been applied in the production of various kinds of heterologous proteins because of its high efficiency. At present, the recombinant expression in P. pastoris has mainly adopted an integrating mode for both single-promoter vectors and dual-plasmid vectors, and the methanol-induced promoter $\mathrm{P}_{A O X}$ was always included $[34,35,55]$. However, the use of methanol in the large-scale production of proteins related to the food and healthcare industries has potential safety hazards due to its toxicity. The biggest advantage of constitutive promoters is that they do not require methanol for induction, and thus have a natural superiority over the AOX1 promoter for the food industry. To avoid the disadvantages caused by methanol induction, the constitutive $\mathrm{P}_{G A P}$ and $\mathrm{P}_{G C W 14}$ promoters were used as independent initiation elements to construct a genome-integrative expression vector and an episomal expression vector in this study, and a novel dual-plasmid-based non-methanol induction P. pastoris expression system was constructed by combining these vectors.

During heterologous protein expression in recombinant $P$. pastoris strains containing a methanol-inducible promoter, the cells grow in the early period and the expression of recombinant proteins by induction takes place later. In contrast, protein expression in recombinant $P$. pastoris strains containing a constitutive promoter can take place along with the cell growth. Thus, an appropriate carbon source and its feed rate are key factors that affect the constitutive expression in large-scale, high-density fermentation processes. P. pastoris is capable of growing on a variety of carbon sources, including glucose, glycerol, oleic acid, and methanol. Methanol utilization is the poorest, glucose is mostly used for a shake flask culture, and glycerol is suitable for large-scale production [26]. A previous study in our laboratory also found that the expression of xylanase XynA using episomal vectors achieved the highest level when glycerol was used as the carbon source [54]. Results of this work proved that the most appropriate feed-flow rate of glycerol was $10 \%$ when $P$. pastoris was constitutively expressing recombinant heterologous proteins, indicating 
that both the appropriate carbon source and feed-flow rate are of vital importance for improving the expression efficiency. Furthermore, relative to methanol-induced expression, the constitutive expression had little effect on the physiological metabolism of the host cells and reduced the pressure on the host during the synthesis and secretion of heterologous proteins, thereby promoting the correct folding of the protein to maintain high specific activity. These properties will be very beneficial for expressing a variety of heterologous proteins with industrial usage on a large scale.

However, the protein yield under the constitutive expression for most enzymes was less than $5 \mathrm{~g} \cdot \mathrm{L}^{-1}$ in high-cell-density fermentation, which was much lower than that of methanol-induced expression. For instance, the constitutive expression level of $\beta$ mannanase from Aspergillus niger CBS 513.88 was $4.5 \mathrm{~g} \cdot \mathrm{L}^{-1}$ [56], and the expression level of endogenous $\beta$-glucanase AfCel12A from $A$. fumigatus was $3-5 \mathrm{~g} \cdot \mathrm{L}^{-1}$ [57]. However, the constitutive expression of $\alpha$-amylase from barley in $P$. pastoris only reached $0.125 \mathrm{~g} \cdot \mathrm{L}^{-1}$ after high-cell-density fermentation [25]. With regard to xylanases, methanol-induction also has obvious superiority compared with traditional constitutive expression. The yield of A. sulphureus-derived xylanase reached $16.41 \mathrm{~g} \cdot \mathrm{L}^{-1}$ after a methanol-induced highdensity fermentation [58], which was the highest value ever reported in a P. pastoris host. Another high yield case was $10.1 \mathrm{~g} \cdot \mathrm{L}^{-1}$ xynB from Thermotoga maritima that was obtained by methanol induction [59], while only $0.37 \mathrm{~g} \cdot \mathrm{L}^{-1}$ XylB from $A$. niger was yielded in $P$. pastoris X-33 after a large-scale fermentation using the constitutive pGAPZ $\alpha A$ vector [60].

In comparison, the yield of XynA reached $13.6 \mathrm{~g} \cdot \mathrm{L}^{-1}$ using the novel dual-plasmid expression system constructed in this study, which was the highest constitutive expression level of xylanase reported so far to our knowledge, and was close to the highest reported methanol-induced yield of xylanase $\left(16.41 \mathrm{~g} \cdot \mathrm{L}^{-1}\right)$ [58]. It indicated that this novel, constitutive, dual-plasmid expression system has a strong expression ability. Further, the fermentation time of this strain was only $102 \mathrm{~h}$, which is shortened by $30 \mathrm{~h}$ compared to the time cycle of methanol-induced, high-density fermentation. In addition, it was not necessary to add selective pressure during high-cell-density fermentation and strain preservation, which will significantly reduce the cost and improve the safety in the industrial fermentation of $P$. pastoris, since the number of reproductive generations in a fermentation cycle was less than 90, and the vectors had high genetic stability over this period. Moreover, since the metabolic pressure caused by glycerol culture on the yeast was significantly less than that caused by methanol induction, the synthesis of high specific activity protein in yeast was also improved. Cultivation using glycerol as the sole carbon source also eliminated the risks of methanol storage and methanol toxicity. All of these advantages give this novel constitutive dual-plasmid system more extensive application potentials in the large-scale production of industrial proteins, especially those that need more safety considerations. In a word, the P. pastoris expression system described here exhibited obvious advantages for the expression of high-value-added heterologous proteins with use in food or drugs, and could promote wider industrial applications of the P. pastoris expression system.

Supplementary Materials: The following are available online at https:/ /www.mdpi.com/article/10 $.3390 /$ cimb43030161/s1.

Author Contributions: W.X.: Conceptualization, methodology, investigation, validation, formal analysis, visualization, writing-original draft, and funding acquisition; M.H. and Y.P.: Conceptualization, methodology, and investigation; D.W.: Conceptualization, methodology, and supervision; J.W.: Funding acquisition, conceptualization, writing-review \& editing, and supervision. All authors have read and agreed to the published version of the manuscript.

Funding: This work was supported by grants from the National Natural Science Foundation of China (31730067, 31801472), the Natural Science Foundation of Jiangsu Province (BK20180604, BK20171261), Jiangsu Provincial Policy Guidance Programme-International Cooperation Projects (BZ2020010), and the national first-class discipline program of Light Industry Technology and Engineering (LITE2018-03). 
Data Availability Statement: Data is contained within the article or supplementary materials.

Conflicts of Interest: The authors declare no conflict of interest.

\section{References}

1. Yang, Z.; Zhang, Z. Engineering strategies for enhanced production of protein and bio-products in Pichia pastoris: A review. Biotechnol. Adv. 2018, 36, 182-195. [CrossRef] [PubMed]

2. Ahmad, M.; Hirz, M.; Pichler, H.; Schwab, H. Protein expression in Pichia pastoris: Recent achievements and perspectives for heterologous protein production. Appl. Microbiol. Biotechnol. 2014, 98, 5301-5317. [CrossRef]

3. Baghban, R.; Farajnia, S.; Rajabibazl, M.; Ghasemi, Y.; Mafi, A.; Hoseinpoor, R.; Rahbarnia, L.; Aria, M. Yeast expression systems: Overview and recent advances. Mol. Biotechnol. 2019, 61, 365-384. [CrossRef] [PubMed]

4. Heistinger, L.; Gasser, B.; Mattanovich, D. Microbe profile: Komagataella phaffii: A methanol devouring biotech yeast formerly known as Pichia pastoris. Microbiology 2020, 166, 614-616. [CrossRef] [PubMed]

5. Madhavan, A.; Arun, K.B.; Sindhu, R.; Krishnamoorthy, J.; Reshmy, R.; Sirohi, R.; Pugazhendi, A.; Awasthi, M.K.; Szakacs, G.; Binod, P. Customized yeast cell factories for biopharmaceuticals: From cell engineering to process scale up. Microb. Cell Fact. 2021, 20, 124. [CrossRef]

6. Spohner, S.C.; Muller, H.; Quitmann, H.; Czermak, P. Expression of enzymes for the usage in food and feed industry with Pichia pastoris. J. Biotechnol. 2015, 202, 118-134. [CrossRef]

7. Love, K.R.; Dalvie, N.C.; Love, J.C. The yeast stands alone: The future of protein biologic production. Curr. Opin. Biotechnol. 2018, 53, 50-58. [CrossRef]

8. Raschmanová, H.; Weninger, A.; Knejzlík, Z.; Melzoch, K.; Kovar, K. Engineering of the unfolded protein response pathway in Pichia pastoris: Enhancing production of secreted recombinant proteins. Appl. Microbiol. Biotechnol. 2021, 105, 4397-4414. [CrossRef] [PubMed]

9. Juturu, V.; Wu, J.C. Heterologous Protein Expression in Pichia pastoris: Latest Research Progress and Applications. Chembiochem A Eur. J. Chem. Biol. 2018, 19, 7-21. [CrossRef] [PubMed]

10. Roghayyeh, B.; Safar, F.; Younes, G.; Mojtaba, M.; Nosratollah, Z.; Naser, S. New developments in Pichia pastoris expression system, review and update. Curr. Pharm. Biotechnol. 2018, 19, 451-467. [CrossRef]

11. Krainer, F.W.; Gerstmann, M.A.; Darnhofer, B.; Birner-Gruenberger, R.; Glieder, A. Biotechnological advances towards an enhanced peroxidase production in Pichia pastoris. J. Biotechnol. 2016, 233, 181-189. [CrossRef]

12. Xia, W.; Bai, Y.; Cui, Y.; Xu, X.; Qian, L.; Shi, P.; Zhang, W.; Luo, H.; Zhan, X.; Yao, B. Functional diversity of family 3 beta-glucosidases from thermophilic cellulolytic fungus Humicola insolens Y1. Sci. Rep. 2016, 6, 27062. [CrossRef]

13. Xia, W.; Xu, X.; Qian, L.; Shi, P.; Bai, Y.; Luo, H.; Ma, R.; Yao, B. Engineering a highly active thermophilic beta-glucosidase to enhance its $\mathrm{pH}$ stability and saccharification performance. Biotechnol. Biofuels 2016, 9, 147. [CrossRef]

14. Yahaya, R.S.R.; Normi, Y.M.; Phang, L.Y.; Ahmad, S.A.; Abdullah, J.O.; Sabri, S. Molecular strategies to increase keratinase production in heterologous expression systems for industrial applications. Appl. Microbiol. Biotechnol. 2021, 105, 3955-3969. [CrossRef] [PubMed]

15. Staley, C.A.; Huang, A.; Nattestad, M.; Oshiro, K.T.; Ray, L.E.; Mulye, T.; Li, Z.H.; Le, T.; Stephens, J.J.; Gomez, S.R.; et al. Analysis of the $5^{\prime}$ untranslated region (5'UTR) of the alcohol oxidase 1 (AOX1) gene in recombinant protein expression in Pichia pastoris. Gene 2012, 496, 118-127. [CrossRef]

16. Waterham, H.R.; Digan, M.E.; Koutz, P.J.; Lair, S.V.; Cregg, J.M. Isolation of the Pichia pastoris glyceraldehyde-3-phosphate dehydrogenase gene and regulation and use of its promoter. Gene 1997, 186, 37-44. [CrossRef]

17. Zhang, X.; Zhang, X.; Liang, S.; Ye, Y.; Lin, Y. Key regulatory elements of a strong constitutive promoter, $P_{\mathrm{GCW} 14}$, from Pichia pastoris. Biotechnol. Lett. 2013, 35, 2113-2119. [CrossRef]

18. Xu, N.; Zhu, J.; Zhu, Q.; Xing, Y.; Cai, M.; Jiang, T.; Zhou, M.; Zhang, Y. Identification and characterization of novel promoters for recombinant protein production in yeast Pichia pastoris. Yeast 2018, 35, 379-385. [CrossRef]

19. Vogl, T.; Glieder, A. Regulation of Pichia pastoris promoters and its consequences for protein production. New Biotechnol. 2013, 30, 385-404. [CrossRef]

20. Vogl, T.; Ruth, C.; Pitzer, J.; Kickenweiz, T.; Glieder, A. Synthetic core promoters for Pichia pastoris. ACS Synth. Biol. 2014, 3, 188-191. [CrossRef] [PubMed]

21. Vogl, T.; Sturmberger, L.; Fauland, P.C.; Hyden, P.; Fischer, J.E.; Schmid, C.; Thallinger, G.G.; Geier, M.; Glieder, A. Methanol independent induction in Pichia pastoris by simple derepressed overexpression of single transcription factors. Biotechnol. Bioeng. 2018, 115, 1037-1050. [CrossRef] [PubMed]

22. Zhang, A.L.; Luo, J.X.; Zhang, T.Y.; Pan, Y.W.; Tan, Y.H.; Fu, C.Y.; Tu, F.Z. Recent advances on the GAP promoter derived expression system of Pichia pastoris. Mol. Biol. Rep. 2009, 36, 1611-1619. [CrossRef]

23. Li, Y.; Zhang, L.; Ding, Z.; Shi, G. Constitutive expression of a novel isoamylase from Bacillus lentus in Pichia pastoris for starch processing. Process Biochem. 2013, 48, 1303-1310. [CrossRef]

24. Zhu, T.; Sun, H.; Li, P.; Xue, Y.; Li, Y.; Ma, Y. Constitutive expression of alkaline $\beta$-mannanase in recombinant Pichia pastoris. Process Biochem. 2014, 49, 2025-2029. [CrossRef]

25. Liu, Z.W.; Yin, H.X.; Yi, X.P.; Zhang, A.L.; Luo, J.X.; Zhang, T.Y.; Fu, C.Y.; Zhang, Z.H.; Shen, J.C.; Chen, L.P. Constitutive expression of barley alpha-amylase in Pichia pastoris by high-density cell culture. Mol. Biol. Rep. 2012, 39, 5805-5810. [CrossRef] 
26. Zhang, A.L.; Zhang, T.Y.; Luo, J.X.; Chen, S.C.; Guan, W.J.; Fu, C.Y.; Peng, S.Q.; Li, H.L. Constitutive expression of human angiostatin in Pichia pastoris by high-density cell culture. J. Ind. Microbiol. Biotechnol. 2007, 34, 117-122. [CrossRef]

27. Wang, X.; Sun, Y.; Ke, F.; Zhao, H.; Liu, T.; Xu, L.; Liu, Y.; Yan, Y. Constitutive expression of Yarrowia lipolytica lipase LIP2 in Pichia pastoris using GAP as promoter. Appl. Biochem. Biotechnol. 2012, 166, 1355-1367. [CrossRef]

28. Liang, S.; Zou, C.; Lin, Y.; Zhang, X.; Ye, Y. Identification and characterization of P GCW14 : A novel, strong constitutive promoter of Pichia pastoris. Biotechnol. Lett. 2013, 35, 1865-1871. [CrossRef]

29. Weinacker, D.; Rabert, C.; Zepeda, A.B.; Figueroa, C.A.; Pessoa, A.; Farías, J.G. Applications of recombinant Pichia pastoris in the healthcare industry. Braz. J. Microbiol. Publ. Braz. Soc. Microbiol. 2014, 44, 1043-1048. [CrossRef]

30. Mariz, F.C.; Coimbra, E.C.; Jesus, A.L.; Nascimento, L.M.; Torres, F.A.; Freitas, A.C. Development of an IP-free biotechnology platform for constitutive production of HPV16 L1 capsid protein using the Pichia pastoris PGK1 promoter. BioMed Res. Int. 2015, 2015, 594120. [CrossRef] [PubMed]

31. Zhan, R.; Mu, W.; Jiang, B.; Zhou, L.; Zhang, T. Efficient secretion of inulin fructotransferase in Pichia pastoris using the formaldehyde dehydrogenase 1 promoter. J. Ind. Microbiol. Biotechnol. 2014, 41, 1783-1791. [CrossRef]

32. Vogl, T.; Gebbie, L.; Palfreyman, R.W.; Speight, R. Effect of plasmid design and type of integration event on recombinant protein expression in Pichia pastoris. Appl. Environ. Microbiol. 2018, 84, e2712-14. [CrossRef] [PubMed]

33. Lin-Cereghino, J.; Wong, W.W.; Xiong, S.; Giang, W.; Luong, L.T.; Vu, J.; Johnson, S.D.; Lin-Cereghino, G.P. Condensed protocol for competent cell preparation and transformation of the methylotrophic yeast Pichia pastoris. BioTechniques 2005, 38, 44-48. [CrossRef] [PubMed]

34. Wu, J.M.; Lin, J.C.; Chieng, L.L.; Lee, C.K.; Hsu, T.A. Combined use of GAP and AOX1 promoter to enhance the expression of human granulocyte-macrophage colony-stimulating factor in Pichia pastoris. Enzyme Microb. Technol. 2003, 33, 453-459. [CrossRef]

35. He, D.; Luo, W.; Wang, Z.; Lv, P.; Yuan, Z. Combined use of GAP and AOX1 promoters and optimization of culture conditions to enhance expression of Rhizomucor miehei lipase. J. Ind. Microbiol. Biotechnol. 2015, 42, 1175-1182. [CrossRef]

36. Tang, C.-D.; Guo, J.; Li, J.-F.; Wei, X.-H.; Hu, D.; Gao, S.-J.; Yin, X.; Wu, M.-C. Enhancing expression level of an acidophilic $\beta$-mannanase in Pichia pastoris by double vector system. Ann. Microbiol. 2013, 64, 561-569. [CrossRef]

37. Parashar, D.; Satyanarayana, T. Enhancing the production of recombinant acidic $\alpha$-amylase and phytase in Pichia pastoris under dual plasmids [constitutive (GAP) and inducible (AOX)] in mixed fed batch high cell density cultivation. Process Biochem. 2016, 51, 1315-1322. [CrossRef]

38. He, X.; Liu, N.; Li, W.; Zhang, Z.; Zhang, B.; Ma, Y. Inducible and constitutive expression of a novel thermostable alkaline $\beta$-mannanase from alkaliphilic Bacillus sp. N16-5 in Pichia pastoris and characterization of the recombinant enzyme. Enzyme Microb. Technol. 2008, 43, 13-18. [CrossRef]

39. Zhu, T.; Guo, M.; Sun, C.; Qian, J.; Zhuang, Y.; Chu, J.; Zhang, S. A systematical investigation on the genetic stability of multi-copy Pichia pastoris strains. Biotechnol. Lett. 2009, 31, 679-684. [CrossRef]

40. Betancur, M.O.; Reis, V.C.B.; Nicola, A.M.; De Marco, J.L.; de Moraes, L.M.P.; Torres, F.A.G. Multicopy plasmid integration in Komagataella phaffii mediated by a defective auxotrophic marker. Microb. Cell Fact. 2017, 16, 99. [CrossRef]

41. Zhu, T.; Guo, M.; Tang, Z.; Zhang, M.; Zhuang, Y.; Chu, J.; Zhang, S. Efficient generation of multi-copy strains for optimizing secretory expression of porcine insulin precursor in yeast Pichia pastoris. J. Appl. Microbiol. 2009, 107, 954-963. [CrossRef]

42. Schwarzhans, J.P.; Luttermann, T.; Wibberg, D.; Winkler, A.; Hubner, W.; Huser, T.; Kalinowski, J.; Friehs, K. A mitochondrial autonomously replicating sequence from Pichia pastoris for uniform high level recombinant protein production. Front. Microbiol. 2017, 8, 780. [CrossRef]

43. Piva, L.C.; Bentacur, M.O.; Reis, V.C.B.; De Marco, J.L.; Moraes, L.M.P.; Torres, F.A.G. Molecular strategies to increase the levels of heterologous transcripts in Komagataella phaffii for protein production. Bioengineered 2017, 8, 441-445. [CrossRef]

44. Nakamura, Y.; Nishi, T.; Noguchi, R.; Ito, Y.; Watanabe, T.; Nishiyama, T.; Aikawa, S.; Hasunuma, T.; Ishii, J.; Okubo, Y.; et al. A Stable, Autonomously replicating plasmid vector containing Pichia pastoris centromeric DNA. Appl. Environ. Microbiol. 2018, 84, e02882-17. [CrossRef] [PubMed]

45. Liachko, I.; Bhaskar, A.; Lee, C.; Chung, S.C.C.; Tye, B.-K.; Keich, U. A comprehensive genome-wide map of autonomously replicating sequences in a naive genome. PLoS Genet. 2010, 6, e1000946. [CrossRef] [PubMed]

46. Camattari, A.; Goh, A.; Yip, L.Y.; Tan, A.H.; Ng, S.W.; Tran, A.; Liu, G.; Liachko, I.; Dunham, M.J.; Rancati, G. Characterization of a panARS-based episomal vector in the methylotrophic yeast Pichia pastoris for recombinant protein production and synthetic biology applications. Microb. Cell Fact. 2016, 15, 139. [CrossRef]

47. Wang, J.; Zhang, T.; Li, Y.; Li, L.; Wang, Y.; Yang, B.; Wang, Y. High-level expression of Thermomyces dupontii thermo-alkaline lipase in Pichia pastoris under the control of different promoters. 3 Biotech 2019, 9, 33. [CrossRef] [PubMed]

48. Moumita, B.; Vishal, K.; Pratyoosh, S. Recombinant approaches for microbial xylanases: Recent advances and perspectives. Curr. Protein Pept. Sci. 2018, 19, 87-99. [CrossRef]

49. Nordberg Karlsson, E.; Schmitz, E.; Linares-Pastén, J.A.; Adlercreutz, P. Endo-xylanases as tools for production of substituted xylooligosaccharides with prebiotic properties. Appl. Microbiol. Biotechnol. 2018, 102, 9081-9088. [CrossRef]

50. Kumar, V.; Dangi, A.K.; Shukla, P. Engineering thermostable microbial xylanases toward its industrial applications. Mol. Biotechnol. 2018, 60, 226-235. [CrossRef]

51. Xu, Y.; Wu, J.; Zheng, K.; Wu, D. A xylanase from Streptomyces sp. FA1: Heterologous expression, characterization, and its application in Chinese steamed bread. J. Ind. Microbiol. Biotechnol. 2016, 43, 663-670. [CrossRef] 
52. Kaufmann, B.P.; Gay, H.; McDonald, M.R. Organizational patterns within chromosomes. In International Review of Cytology; Bourne, G.H., Danielli, J.F., Eds.; Academic Press: Cambridge, MA, USA, 1960; Volume 9, pp. 77-127.

53. Wu, D.; Ma, D.; Hao, Y.Y.; Chu, J.; Wang, Y.H.; Zhuang, Y.P.; Zhang, S.L. Incomplete formation of intramolecular disulfide bond triggers degradation and aggregation of human consensus interferon-alpha mutant by Pichia pastoris. Appl. Microbiol. Biotechnol. 2010, 85, 1759-1767. [CrossRef]

54. Pan, Y.; Wu, D.; Wu, J. Improving the expression of recombinant xylanase in Pichia pastoris with episomal expression plasmid. Sheng Wu Gong Cheng Xue Bao = Chin. J. Biotechnol. 2018, 34, 712-721. (In Chinese) [CrossRef]

55. Ozturk, S.; Ergun, B.G.; Calik, P. Double promoter expression systems for recombinant protein production by industrial microorganisms. Appl. Microbiol. Biotechnol. 2017, 101, 7459-7475. [CrossRef]

56. Zheng, J.; Zhao, W.; Guo, N.; Lin, F.; Tian, J.; Wu, L.; Zhou, H. Development of an industrial medium and a novel fed-batch strategy for high-level expression of recombinant beta-mananase by Pichia pastoris. Bioresour. Technol. 2012, 118, 257-264. [CrossRef] [PubMed]

57. Várnai, A.; Tang, C.; Bengtsson, O.; Atterton, A.; Mathiesen, G.; Eijsink, V.G.H. Expression of endoglucanases in Pichia pastoris under control of the GAP promoter. Microb. Cell Fact. 2014, 13, 57. [CrossRef]

58. Yang, W.; Yang, Y.; Zhang, L.; Xu, H.; Guo, X.; Yang, X.; Dong, B.; Cao, Y. Improved thermostability of an acidic xylanase from Aspergillus sulphureus by combined disulphide bridge introduction and proline residue substitution. Sci. Rep. 2017, 7, 1587. [CrossRef]

59. Jia, H.; Fan, G.; Yan, Q.; Liu, Y.; Yan, Y.; Jiang, Z. High-level expression of a hyperthermostable Thermotoga maritima xylanase in Pichia pastoris by codon optimization. J. Mol. Catal. B Enzym. 2012, 78, 72-77. [CrossRef]

60. Karaoglan, M.; Karaoglan, F.E.; Inan, M. Comparison of ADH3 promoter with commonly used promoters for recombinant protein production in Pichia pastoris. Protein Expr. Purif. 2016, 121, 112-117. [CrossRef] [PubMed] 